Bolton quickly established a commanding position as analyst, consultant and technical adviser in the oil and fat and many food industries. In 1920, Tochnical Research Works Ltd. was founded, with premises in Milner Street, Sloane Square, Bolton being. managing director, and transferring his analytical and consulting practice to the same address. 1920 is notable, too, in that it is the date of Bolton's patent for the continuous hydrogenation of unsaturated oils, fats and the like.

Much original work came from Bolton's fertile mind and clever hands: it was published mostly in the Analyst, from the year 1910, his last two papers (with K. A. Williams) being in 1938, both dealing with whale oil: his aptitude in devising apparatus and instruments is exemplified in the Bolton and Williams colorimeter. He also served on a number of research committees, particularly on analytical methods; at the time of his death he had just begun work with the "S.P.A." Sub-Committee on the determination of unpolymerisable matter in oils. Outstanding among his publications, there appoared in 1911 his book "Fatty Foods" (Bolton and Revis) a second edition of which, with the title "Oils, Fats and Fatty Foods" (Bolton) came in 1928.

Bolton was a well-known member of many societies; particular mention should be made of his services to the Society of Public Analysts and Other Analytical Chemists, of which he was honorary secretary from 1915 until 1925 and president during 1926-1927. For a period he was honorary treasurer of the Federal Council for Chemistry, and later was a member of the British Council for Chemistry of the Royal Society, a member of the delegacy of King's College, London, and a Royal Institution Visitor.

Seemingly in the full vigour of life, Bolton died, suddenly, after an illness from which he was thought to be recovering, leaving a widow and a host of friends to lament his loss. He was a remarkable and muchloved man, held in universal regard and affection alike by his staff, his colleagues and a wide circle of professional and business friends. His death is a serious loss to the profession of chemistry; yet throughout his life he did much to minimize this loss, for generosity in giving to others the fruits of his own gifted mind and of his wide experience was a notable characteristic of his ever-generous nature.

E. HrNks.

\section{Prof. C. C. Okell}

Prof. Charles Cyril Okell, who died on February 9, was educated at Douglas Grammar School, St. John's College, Cambridge, and St. Bartholomow's Hospital, and distinguished himself as a student. He became medically qualified during the Great War and served in the R.A.M.C. as lieutenant and captain in France, Palestine and Egypt, and was awarded the Military Cross when a regimental medical officer. Soon after the War he became bacteriologist to the Wellcome Physiological Research Laboratories at Beckenham, and loft that institution to become professor of bacteriology at
University College Hospital Medical School, London. He was for some time assistant editor of the Journal of Pathology and Bacteriology and at the time of his death was editor of the Journal of Hygiene.

Okell's active scientific life began at Beckenham. Ho was soon engaged in what has since become one of the main labours of the laboratory - the investigation of the problem of human immunization against diphtheria. He collaborated with Glenny in an important paper on the meaning of the Ramor flocculation test for diphtheria antitoxin. This was followed by a large volume of work on the problem of immunization against scarlet fever and a number of papers on the hæmolytic streptococcus and its toxin. $\mathrm{He}$ was also concerned in a comprehensive examina. tion of the sugar reactions of the diphtheria bacillus and the development of an intracutaneous test for the virulence of diphtheria bacilli which made the routine testing of virulence much cheaper and more practical. $\mathrm{He}$ also published papers on the standardization of dysentery antitoxin, scarlet fover antitoxin and tuberculin, and was among the first to realize the importance of the application of statistical methods to biological assay.

Okell was part author of a paper which was perhaps the first to establish with statistical rigour the fact that 'B.C.G.' had some immunizing power against virulent tubercle bacilli. One of his last efforts at Beckenham was his attempt with Hindle to establish the possibility of vaccination against yellow fever, an exciting and dangerous piece of work, which he approached in the same spirit of detachment which characterized all his efforts.

On his appointment to the chair at University College Hospital Medical School, Okell delivered the Milroy Lectures in 1932, in which he summarized the fruit of his labours for many years on the hæmolytic streptococcus. $\mathrm{He}$ also mado the discovery that simple operations such as tooth extractions are followed in a large number of cases by the appearance of streptococci in the blood of the patients, a most important observation which he would have followed up but for the rapid onset of the ailment which led to his retirement to Cambridge.

All Okell's work was done in collaboration with others. He loved the company of his fellows both in work and in leisure. He did not like working alone, and always discussed what he was doing with all and sundry. He was a great conversationalist, and was always worth listening to, not only when talking of his special subject, but also when ranging at large over literature, art and ethics. In none of the work in which he collaborated was his contribution the least important factor and he was generally the moving spirit. His work was never far removed from practical application. Interested though he was in fundamental problems, it could be seen that the motive of his work was primarily the benefit of the sick, particularly in the prevontion of disease.

Okell was universally popular, and the gradual restriction of the field of his labours by his illness was a grief to all of his friends. He leaves a memory of care for others and single-hearted devotion to medicine which will endure.
J. W. Trevan. 